\title{
Planting Densities and Forms of Potassium Fertilization in the Development of Edamame (Glycine $\max$ (L.) Merril) Cultivation
}

\author{
Raphael Henrique da Silva Siqueira ${ }^{1}$, Oscar José Smiderle ${ }^{2}$, João Luiz Lopes Monteiro Neto ${ }^{3}$, \\ Sonicley da Silva Maia ${ }^{3}$, Railin Rodrigues de Oliveira ${ }^{3}$, Edgley Soares da Silva ${ }^{3}$, Carlos Enrique Canche Iuit ${ }^{3}$, \\ Kedma da Silva Matos ${ }^{3} \&$ Carlos Abanto-Rodriguez ${ }^{4}$ \\ ${ }^{1}$ Federal Institute of Education, Science and Technology of Roraima (IFRR), Campus Amajari, RR, Brazil \\ ${ }^{2}$ Brazilian Corporation of Agricultural Research (EMBRAPA), Boa Vista, RR, Brazil \\ ${ }^{3}$ Federal University of Roraima, Campus Cauame (UFRR), Boa Vista, RR, Brazil \\ ${ }^{4}$ Researchs Institute of the Peruvian Amazon (IIAP), Yarinacocha, Ucayali, Peru \\ Correspondence: Carlos Abanto-Rodriguez, Researchs Institute of the Peruvian Amazon, Yarinacocha, Ucayali, \\ Peru. E-mail: carforestal24@gmail.com
}

Received: April 16, 2019

doi:10.5539/jas.v11n16p11
Accepted: July 12, 2019 Online Published: September 30, 2019

URL: https://doi.org/10.5539/jas.v11n16p11

\begin{abstract}
The edamame is the soybean harvested in the R6 phenological period when the seed in green. That is the reason of its name, Green Soybean. To evaluate the influence of different planting densities and two types of potassium fertilizer on the agronomic components of the edamame cultivar BR 9452273, an experiment was conducted in the municipality of Boa Vista-RR between early 2015 and March 2016. The experimental design was a complete randomized block design in a $4 \times 2$ factorial scheme with four plant densities $(140,160,200$ and 240 thousand plants $\mathrm{ha}^{-1}$ ) and two forms of potassium fertilization in the last split-application (potassium chloride- $\mathrm{KCl}$ (control) and a Leaf fertilizer-K-20) on the same concentration $\left(30 \mathrm{~kg} \mathrm{ha}^{-1}\right)$ for both treatments, with three replicates. Plant cultivation variables were evaluated, as well aspod productivity and the reproductive and maturation periods of the plants. Based on the results obtained, the BR-9452273 edamame lineage showed early growth and maturation under local edaphoclimatic conditions, with reproductive and maturation periods of 24 and 73 days after planting, respectively. Plant height and the insertion of the first pod, the diameter of the stem, and pod number in a sample of $500 \mathrm{~g}$ were affected by the joint action of the evaluated factors. Green pod yield and total biomass were favored by both higher and lower density, which alongside the application of $\mathrm{KCl}$, were the most effective treatments for production of edamame in the Cerrado of Roraima.
\end{abstract}

Keywords: green soybean, cerrado, familiar agriculture

\section{Introduction}

Recently introduced into Brazil, edamame soybean (Glycine max L. Merril) have aroused great interest in the population because of their special characteristics, including high protein content, high organoleptic quality, the absence of lipoxygenases and reduced levels of Trypsin inhibitors, in addition to being a natural alternative for hormone replacement (Charlo et al., 2008). The pods are harvested at the R6 stage of the development of the species, where the beans are completely green, larger, sweeter and tenderer than the common "soya", and occupy $80 \%$ to $90 \%$ of the pod width (Zhang et al., 2010).

Although much of the production and consumption of this vegetable occurs in Asian countries such as Japan, China and Korea (Carrão-Panizzi, 2006), recent studies have found several genotypes of this species adapt well to several regions in Brazil (Charlo et al., 2008; Smiderle et al., 2009; Santos et al., 2013). According to Moraes et al. (2004), the adaptability of edamame to different environmental conditions is a result of extensive prior agronomic development. Just like soya, where capacities are expressed strongly by the cultivation management and the agronomic practices.

According to Argenta et al. (2001), planting density is a determinant factor in plant development and crop productivity because overly-high densities can produce competition for soil resources, especially water and nutrients, as well as for solar radiation (Petter et al., 2016). Mendonça et al. (2003) indicate planting densities ranging from 166 to 400 thousand plants $\mathrm{ha}^{-1}$, with planting occurring at a spacing of $0.5 \mathrm{~m}$ between rows and 
0.05 to $0.12 \mathrm{~m}$ between plants for the spring/summer cultivation. While for autumn/winter cultivation, 208 to 500 thousand plants $\mathrm{ha}^{-1}$, at a spacing of $0.4 \mathrm{~m}$ between rows and 0.05 to $0.12 \mathrm{~m}$ between plants.

However, due to the great territorial extension of Brazil and the extensive edaphic and climate variation within it, one-off studies are necessary to determine which planting densities for soybeans are more appropriate for each region.

In addition to plant density, the development of edamame is directly affected by the type of fertilization used (Lima \& Smiderle, 2013). Potassium (K) is of fundamental importance for the successful production of edamame crops. Besides promoting the synthesis of photoassimilates and their transport to seeds and plant storage organs, this essential nutrient is involved in the conversion of starch, protein, vitamins, and oils, among others (Mengel \& Kirkby, 1987; Cecílio Filho \& Grangeiro, 2004).

Edamame extracts large volumes of $\mathrm{K}$ from the soil. However, due to the high degree of weathering Cerrado soils have low $\mathrm{K}$ content, and the natural reserves of this nutrient do not support successive edamame crops. This makes it necessary to return and supplement this nutrient through K fertilization (Aratani et al., 2007).

Therefore, for greater economy of $\mathrm{K}$ fertilizers and cultivated area, information that subsidizesthe cultivation of edamame should be seeked, but also try to introduce this soybean in the food habits and income of small farmers in the northern region. This work sought to evaluate the influence of plant density and the K fertilization type on the agronomic development of edamame cultivated in the Cerrado of Boa Vista, at Roraima State, Brazil.

\section{Research Methods}

\subsection{Experimental Area}

The experiment was carried out in the Embrapa Roraima experimental station, in the municipality of Boa Vista-RR. The site is located as $2^{\circ} 45^{\prime} 26.6^{\prime \prime} \mathrm{N} ; 60^{\circ} 43^{\prime} 49^{\prime \prime} \mathrm{W}$, at an altitude of $90 \mathrm{~m}$. Studies were conducted between October 2015 and March 2016. The climate of the region is Köppen type Aw, tropical rainy, with annual averages of precipitation, relative humidity, and temperature of $1.678 \mathrm{~mm}, 70 \%$, and $27.4^{\circ} \mathrm{C}$, respectively (Araújo et al., 2001).

The edamame cultivar used was BR-9452273, planted in a typical weathered Yellow (LAdx) with the following

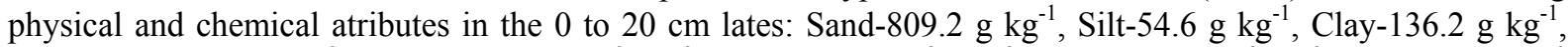
pH-5.4; P-2.51 mg dm${ }^{-3} ; \mathrm{K}^{+}-0.05 \mathrm{cmol}_{\mathrm{c}} \mathrm{dm}^{-3} ; \mathrm{Ca}^{2+}-0.84 \mathrm{cmol}_{\mathrm{c}} \mathrm{dm}^{-3} ; \mathrm{Mg}^{2+}-0.40 \mathrm{cmol}_{\mathrm{c}} \mathrm{dm}^{-3} ; \mathrm{Al}^{3+}-0.04 \mathrm{cmol}_{\mathrm{c}} \mathrm{dm}^{-3}$; $\mathrm{H}+\mathrm{Al}^{3+}-1.82 \mathrm{cmol}_{\mathrm{c}} \mathrm{dm}^{-3}$; Organic material-10.19 $\mathrm{g} \mathrm{kg}^{-1} ; \mathrm{CTC}_{\mathrm{t}}-3.11 \mathrm{cmol}_{\mathrm{c}} \mathrm{dm}^{-3}$ (Embrapa, 2013).

\subsection{Experimental Design and Conduction}

The experimental design used was a randomized block, with treatments arranged in a $4 \times 2$ factorial with four plant densities $\left(140,160,200\right.$, and 240 thousand plants $\left.\mathrm{ha}^{-1}\right)$, which were implemented as plantings of 7, 8, 10, and 12 plants per linear meter, and two forms of $\mathrm{K}$ fertilization (Potassium chloride- $\mathrm{KCl}$ and foliar fertilizer-K-20), with three replications. The experimental plot consisted of four $2.0 \mathrm{~m}$ lines spaced at $0.5 \mathrm{~m}$.

At the planting, $400 \mathrm{~kg} \mathrm{ha}^{-1}$ of mineral fertilizer of the formula (NPK) 2-24-12 was applied, equivalent to $8 \mathrm{~kg}$ $\mathrm{ha}^{-1}$ of $\mathrm{N}, 96 \mathrm{~kg} \mathrm{ha}^{-1}$ of $\mathrm{P}$, and $48 \mathrm{~kg} \mathrm{ha}^{-1}$ of $\mathrm{K}$ per sowing line. As a result of soil analysis, and following the recommendation of Smiderle et al. (2009), deposits were spaced every $0.50 \mathrm{~m}$.

For $\mathrm{K}$ fertilization, $48 \mathrm{~kg} \mathrm{ha}^{-1}$ was applied at planting and $20 \mathrm{~kg} \mathrm{ha}^{-1}$ of $\mathrm{KCl}$ was applied at the beginning of flowering at all evaluated planting densities. The remainder of the $\mathrm{K}\left(30 \mathrm{~kg} \mathrm{ha}^{-1}\right)$ was applied, either as $\mathrm{K}-20$ (foliar fertilizer with $\left.20 \% \mathrm{~K}_{2} \mathrm{O}\right)$ or $\mathrm{KCl}\left(60 \% \mathrm{~K}_{2} \mathrm{O}\right)$ when seed expansion began.

The plants were sprinkle irrigated daily, until plants reached the R6 stage of development when they were removed from the soil and taken to the Embrapa-RR Seed Technology Laboratory for manual removal of pods and evaluation.

\subsection{Dependent Variables}

Variables tested were: number of days for maturation (NDM) and reproductive period (PR). These variables (NDM and PR) were obtained by counting the number of days from planting to flowering and planting to stage R6, respectively. Plant height (AP) and height of insertion of the first pod (APV) were measured with a graduated ruler. The first was measured from the level of the ground to the apex of the stem and the second from the same initial level to the level of insertion of the first pod; Stem diameter (DC), was measured with digital callipers; Number of pods in $500 \mathrm{~g}$ samples (NV/500 g); green pod productivity (PVV) was obtained by weighing the pods and estimated to one hectare; and total biological productivity (PBT), was measured via the combined wet weight of aerial and root plant parts. 


\subsection{Data and Statistical Analysis}

Data were analyzed with analysis of variance and, depending on $\mathrm{F}$ test values, regression analysis were performed on all analyzed variables, at $5 \%$ probability, with the aid of SISVAR ${ }^{\circledR} 5.0$ software (Ferreira, 2011).

\section{Results and Discussion}

\subsection{Reproductive and Maturation Periods}

Plant densities and $\mathrm{K}$ sources did not affect the reproductive and maturation periods of the tested edamame cultivar as this occurred at 24 and 73 days after planting, respectively, for all treatments. Such results could indicate a high precocity of this cultivar in relation to those studied by Charlo et al. (2011) who, when evaluating ten edamame cultivars at different planting densities, reported maturation periods ranging from 97 to 120 days after sowing. Therefore, in addition to adapting to the influence of local climatic factors, BR-9452273 demonstrated great stability in reproductive maturation and periodicity.

\subsection{Morphological and Productive Characteristics}

The significant effect of the interaction between planting densities and a form of $\mathrm{K}$ fertilization on edamame plant development was studied via plant height (AP), first pod insertion height (APV), stem diameter (DC), and the number of pods in $500 \mathrm{~g} / 500 \mathrm{~g}$. Only planting density had a significant effect on green pod yield (PVV) and total biological productivity (PBT) (Table 1).

Table 1. Summary of analysis of height insertion of the first pod (APV), plant height (AP), stem diameter (DC), number of pods in a $500 \mathrm{~g}$ sample (NV/500g), green pod productivity (PVV), number of pods per plant (NVP), and total biological productivity (PBT) of edamame grown under two fertilization sources and four planting densities. Boa Vista, RR, 2016

\begin{tabular}{llllllll}
\hline \multirow{2}{*}{ FV } & \multirow{2}{*}{ GL } & \multicolumn{5}{c}{ Variable } \\
\cline { 3 - 7 } & & AP & APV & DC & NV/500g & PVV & PBT \\
\hline Block & 2 & $1.85^{\text {ns }}$ & $0.85^{\text {ns }}$ & $0.18^{\text {ns }}$ & $6.1^{\text {ns }}$ & $2941.85^{\text {ns }}$ & $2609.45^{\text {ns }}$ \\
K type (F) & 1 & $13.68^{\text {ns }}$ & $5.57^{*}$ & $8.45^{* *}$ & $260.0^{* *}$ & $181.12^{\text {ns }}$ & $575.05^{\text {ns }}$ \\
Planting Density (D) & 3 & $19.73^{*}$ & $14.02^{*}$ & $5.88^{* *}$ & $2155.1^{* *}$ & $22280.35^{* *}$ & $84535.63^{* *}$ \\
F $\times$ D & 3 & $55.63^{* *}$ & $8.59^{* *}$ & $1.43^{*}$ & $313.5^{* *}$ & $2516.90^{\text {ns }}$ & $10539.10^{\text {ns }}$ \\
Error & 14 & 5.19 & 0.94 & 0.33 & 13.7 & 1569.55 & 6647.96 \\
\hdashline C.V. $(\%)$ & & 4.65 & 4.65 & 9.79 & 13.20 & 9.15 & 9.66 \\
\hline
\end{tabular}

Note. ns, ${ }^{*}, * *$ : not significant, significant at $5 \%$, and significant at $1 \%$ levels, respectively F-test.

\subsection{Plants Height}

The application of fertilizers combined with increased plant density resulted in a quadratic plant height (AP) response, where planting density, with 240 and $187.04 \mathrm{ha}^{-1}$ plants resulted in maximum physical expression for this character (54 and $52.04 \mathrm{~cm}$ ) for $\mathrm{KCl}$ and $\mathrm{K}-20$, respectively (Figure 1).

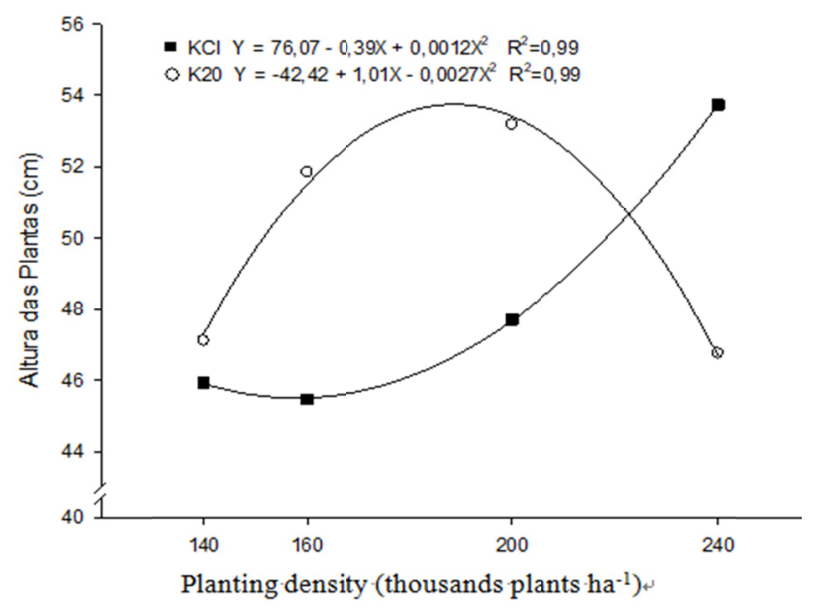

Figure 1. The height of edamame plants as a function of planting densities and form of K fertilization 
At these experimental planting densities, some etiolation may have occurred due to increased inter-individual competition for water, nutrients and, principally, for sunlight. This could explain the greater plant heights recorded with treatments using $\mathrm{KCl}$ (Mauad et al., 2010). In addition, according to Martins et al. (1999), higher competition lowers levels of photoassimilate availability for branch-based vegetative growth so that, under such circumstances, growth occurs preferentially via the main stem. This has also been reported by Souza et al. (2010), and Cruz et al. (2016).

According to Harms et al. (2015), increasing plant density directly influences leaf wetting, which may have resulted in a lower $\mathrm{K}$ absorption efficiency when the K-20 foliar feed was applied, causing a decrease in plant height at higher densities due to an overall reduction of $\mathrm{K}_{2} \mathrm{O}$ availability.

In addition, Rocha et al. (2012) have reported that height variations of edamame plants occur as a result of a variety of factors: sowing time, spacing, water supply, temperature, soil fertility, latitude, variation in cultivars response to photoperiod, and other environmental conditions. All of which reinforces the need to test the productive capacity of different genotypes across the greatest possible variety of regions.

\subsection{First Pod Insertion}

For the height of first pod insertion (APV), application of $\mathrm{KCl}$ and $\mathrm{K}-20$ showed linear and quadratic behavior, respectively, with the increased planting densities. At the modeled density of 190,000 plants $\mathrm{ha}^{-1}$, edamame plants fertilized with K-20 had higher APV.

These results support the assertion of Carpenter and Board (1997), that the height of insertion of the first pod in soya culture is positively correlated with plant height, as similar behavior was observed with different plant densities and the $\mathrm{K}$ fertilization variables (Figures 1 and 2).

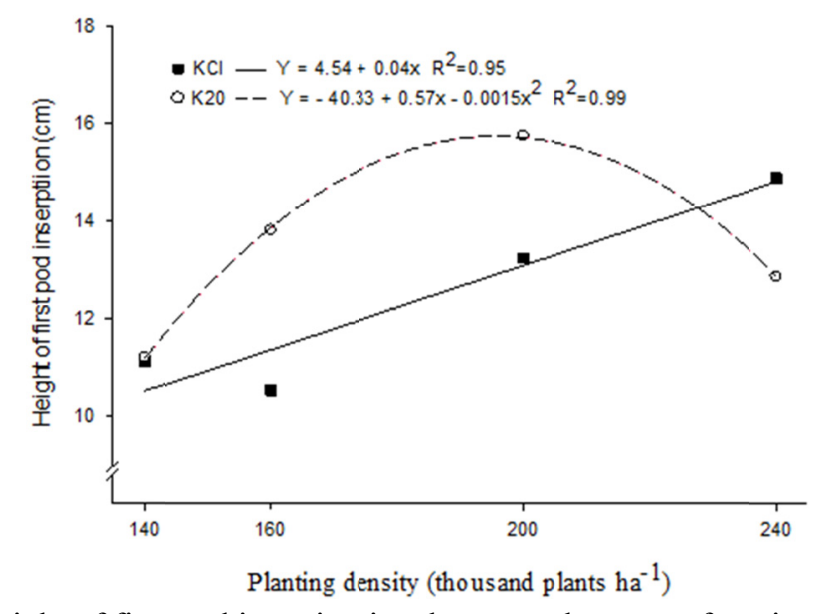

Figure 2. The height of first pod insertion in edamame plants as a function of plant densities and form of $\mathrm{K}$ fertilization

In general, the plants showed good results for APV, considering that, usually, cultivars with APV ranging from 10 to $15 \mathrm{~cm}$ are sought (Peluzio et al., 2009). However, according to Monteiro et al. (2015), the ideal APV for soybeans and edamame requires further discussion, once harvesting occurs by cutting the plant still green and just then removing the pods. For common soybeans, this variable is extremely important in reducing the crop losses, allowing the harvester's cutting bar to be positioned so that maximum efficiency is obtained during the harvesting process (Mauad et al., 2010).

\subsection{Plants Diameter}

Stem diameter decreased with increasing planting density with both sources of $\mathrm{K}$ fertilization. However, this behavior had a quadratic curve following $\mathrm{KCl}$ application, while when following $\mathrm{K}-20$ there was a linear effect. At lower density, a diameter significantly higher than the other treatments was observed to be associated with the application of $\mathrm{KCl}$ (Figure 3). 


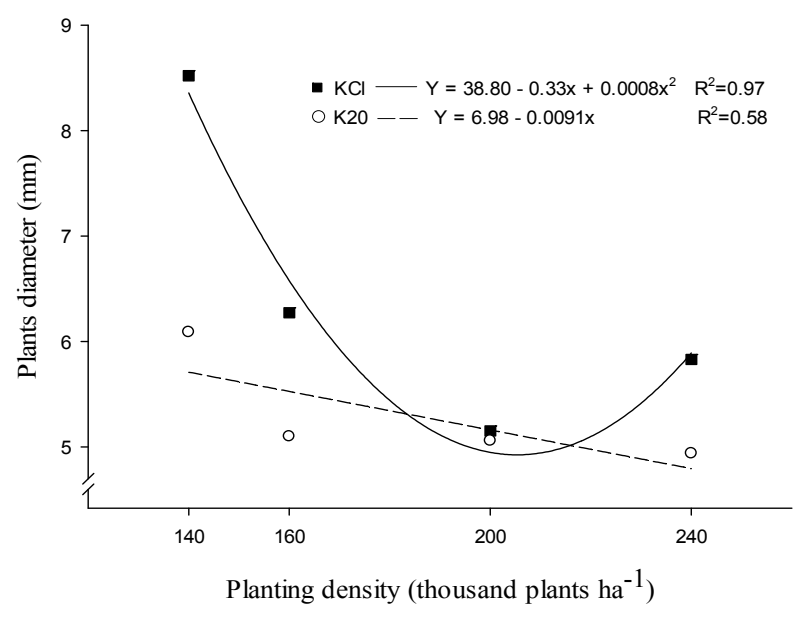

Figure 3. The diameter of the edamame plants as a function of planting density and $\mathrm{K}$ fertilization

A higher availability of $\mathrm{K}$ within the application of $\mathrm{KCl}$ and a greater availability of solar radiation found with at lowest planting density may have favored the development of plant diameters under this regime. These results corroborate with those of Machado et al. (2009), who observed a mean diameter of $4.12 \mathrm{~mm}$ for soybean cultivars at a density of 240,000 plants ha ${ }^{-1}$, and of Watanabe et al. (2005), who found that the lower the density of soybean plants, the greater the stem diameter.

\subsection{Number of Pods in $500 \mathrm{~g}$ Samples and Green Pod Productivity}

Values for the number of pods in $500 \mathrm{~g}$ samples (NV $500 \mathrm{~g}$ ), was similar for both forms of K fertilization. However, greatest yield was obtained with $\mathrm{KCl}$ applied to plantings at a density of 211 thousand ha ${ }^{-1}$ (334 pods), with the second greatest being for K-20 fertilized plants at a density of 192,000 plants ha ${ }^{-1}$ (326 pods) (Figure 4).

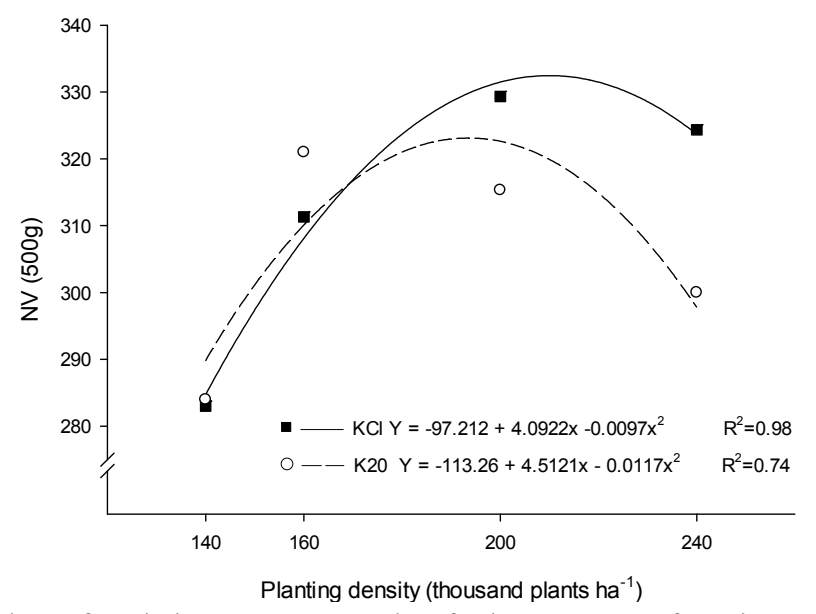

Figure 4. Number of pods in a $500 \mathrm{~g}$ sample of edamame as a function of plant density and forms of $\mathrm{K}$ fertilization

Greatest results were obtained with planting densities between 180 and 220 thousand ha ${ }^{-1}$ plants. However, for edamame, consumer preference is for the relatively large green seeds that occur mainly with genotypes that have fewer pods (Charlo et al., 2011).

Therefore, a higher number of pods does not indicate a higher product quality since it may be due to a large number of small pods, so indicating that planting densities producing smaller pods also produced a greater number of larger grains. This was confirmed by green pod productivity (PVV) results, where high productivity was found in the treatments with the lowest number of pods (Figures 4 and 5), possibly because of the reduced competition for light, water, and soil nutrients (Mouada et al., 2010). 


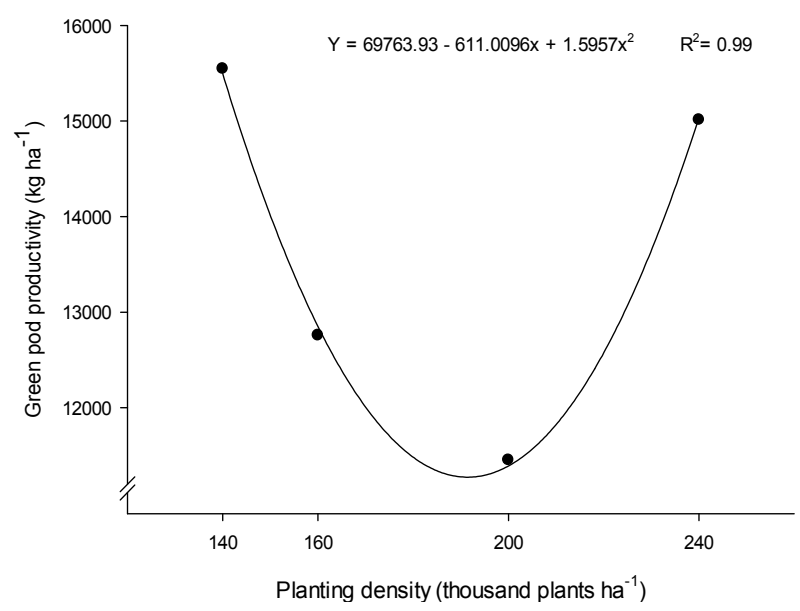

Figure 5. Productivity of edamame green pods at different planting densities

In addition to the lower planting density, the greater number of plants, regardless of potassium fertilization, may also have influenced green pod yield. Such results are in agreement with those obtained by Tourino et al. (2002), Charlo et al. (2008), and Vazquez et al. (2008), who found little difference in productivity between largest and smallest plant populations, indicating a compensation in productivity linked to the greater plant densities.

\subsection{Total Biological Productivity}

A similar effect to that recorded for PVV was observed for total biological productivity (PBT) (Figure 6), with the highest values found in the lowest and highest planting densities. Again, this is possibly due to productivity compensation due to the higher densities.

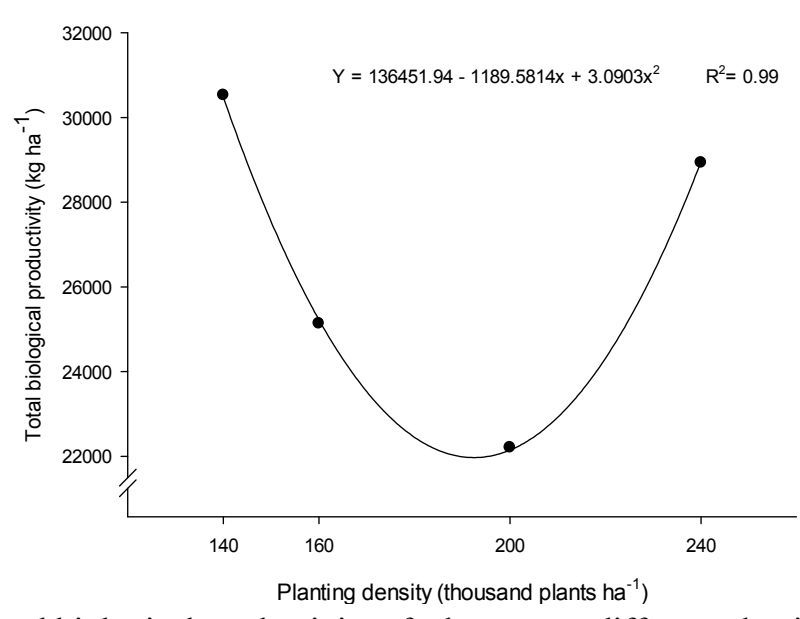

Figure 6. Total biological productivity of edamame at different planting densities

This variable, in particular, is of great value if green manuring is to be part of the management regime, since the soybean plants are relatively high in biomass and contain large amount of nutrients extracted from the soil and the atmosphere, and these can be reincorporated in the soil for successive plantings (Padovan et al., 2002).

Although there is little difference in PBT between the highest and the lowest planting density, in use for green manure lower density plantings, could be most appropriate because of the lower seed requirement. However, planting densities lower than those used in the current study may not contribute satisfactorily to the good development of edamame in Cerrado of Roraima (Monteiro et al., 2015).

Application of $\mathrm{K}$ fertilizer via the leaves is a potential option when the soil and climatic conditions do not favor $\mathrm{K}$ absorption from the soil. However, in general, leaf-based fertilizer application is not as compatible with commercial development of edamame as the use of $\mathrm{KCl}$. 


\section{Conclusions}

The edamame cultivar BR-9452273 has good stability in terms of its reproductive and maturation periods in the Roraima Cerrado.

Potassium chloride supplementation when planting seeds is more efficient than the foliar fertilization for edamame development.

A density of 140,000 plants $\mathrm{ha}^{-1}$ is the most suitable for the cultivation of edamame BR-9452273 in Roraima Cerrado soils and climate.

\section{References}

Aratani, R. G., Lazarini, E., \& Marques, R. R. (2007). Adubação potássica na cultura da soja em duas épocas de semeadura. Revista Brasileira Ciências Agrárias, 2(3), 206-211. https://doi.org/10.5039/agraria.v2i3a22

Araújo, W. F., Andrade Júnior, A. S., Medeiros, R. D., \& Sampaio, R. A. (2001). Precipitação pluviométrica provável em Boa Vista, Estado de Roraima, Brasil. Revista Brasileira de Engenharia Agríclo e Ambiental, 5(3), 563-567. https://doi.org/10.1590/S1415-43662001000300032

Argenta, G., Silva, P. R. F., \& Sangol, L. (2001). Arranjo de plantas em milho: Análise do estado-da-arte. Ciência Rural, 31(6), 1075-1084. https://doi.org/10.1590/S0103-84782001000600027

Carpenter, A. C., \& Board, J. E. (1997). Branch yield components controlling soybean yield stability across plant populations. Crop Science, 37(3), 885-891. https://doi.org/10.2135/cropsci1997.0011183X003700030031x

Carrão-Panizzi, M. C. (2006). Edamame ou soja-hortaliça: Fácil de consumir e muito saudável. Informe Agropecuário, 27(230), 59-64.

Cecílio Filho, A. B., \& Grangeiro, L. C. (2004). Qualidade de frutos de melancia sem sementes em função de fontes e doses de potássio. Ciência e Agrotecnologia, 28(3), 570-576. https://doi.org/10.1590/S1413-70542 004000300011

Charlo, H. C. O., Castoldi, R., \& Vargas, P. F. (2008). Desempenho de genótipos de soja-hortaliça de ciclo precoce [Glycine max (L.) Merril] em diferentes densidades. Ciência e Agrotecnologia, 32(2), 630-634. https://doi.org/10.1590/S1413-70542008000200044

Charlo, H. C. O., Pessoa, R., Funichello, M., Castoldi, R., \& Braz, L. T. (2011). Desempenho agronômico de dez linhagens de soja-hortaliça. Horticultura Brasileira, 29(3), 349-353. https://doi.org/10.1590/S0102-0536 2011000300015

Cruz, S. C. S., Sena-Junior, D. G., Santos, D. M. A., Lunezzo, L. O., \& Machado, C. G. (2016). Cultivo de soja sob diferentes densidades de semeadura e arranjos espaciais. Revista Agricultura Neotropical, 3(1), 1-6. https://doi.org/10.32404/rean.v3i1.431

Ferreira, D. F. (2011). Sisvar: A computer statistical analysis system. Ciência e Agrotecnologia, 35(6), 1039-1042. https://doi.org/10.1590/S1413-70542011000600001

Harms, M. G., Pria, M. D., Rezende, B. L. A., Prestes, A. M. C., \& Dalazoana, F. (2015). Influência da densidade de plantas e do uso de fungicida nas doenças foliares e na produtividade de cebola. Horticultura Brasileira, 33(2), 203-207. https://doi.org/10.1590/S0102-053620150000200011

Lima, J. M. E., \& Smiderle, O. J. (2013). Potencial fisiológico de sementes de soja-hortaliça produzidas com diferentes adubações e armazenadas por doze meses. Revista Agro@mbiente On-line, 7(1), 70-79. https://doi.org/10.18227/1982-8470ragro.v7i1.801

Machado, G. S., Peixoto, P. C., Rangel, M. A. S., Borges, V. P., Bloisi, A. M., Bloisi, L. F. M., \& Silva, A. L. L. (2009). Adaptação de Genótipos de Soja Hortaliça no Município de Cruz das Almas-BA. Revista Brasileira de Agroecologia, 4(2), 3115-3118.

Martins, M. C., Câmara, G. M. S., Peixoto, C. P., Marchiori, L. F. S., Leonardo, V., \& Mattiazzi, O. (1999). Épocas de semeadura, densidades de plantas e desempenho vegetativo de cultivares de soja. Scientia Agricola, 56(4), 851-858. https://doi.org/10.1590/S0103-90161999000400012

Mauad, M., Silva, T. L. B., Almeida Neto, A. I., \& Abreu, V. G. (2010). Influência da densidade de semeadura sobre características agronômicas na cultura da soja. Agrarian, 3(9), 175-181.

Mendonça, J. L., Aragão, F. A. S., \& Costa, A. C. (2003). Influência de espaçamentos entre plantas nas linhas em características morfo-agronômicas de soja hortaliça. Horticultura Brasileira, 21, 92-96. 
Mengel, K., \& Kirkby, E. A. (1987). Principles of plant nutrition (p. 687)

Monteiro, A. N. L., Alves, J. M. A., Matos, W. S., Silva, M. R., Silva, D. L., \& Barreto, G. F. (2015). Densidade de plantas e doses de NPK nos componentes de produção de soja-hortaliça na Savana de Roraima. Revista Agro@mbiente On-line, 9(4),352-369.https://doi.org/10.18227/1982-8470ragro.v9i4.2638

Moraes, J. C. C., Peixoto, C. P., Santos, J. M. B., Brandelero, E., Peixoto, M. F. S. P., \& Silva, V. (2004). Caracterização de dez cultivares de soja nas condições agroecológicas do Recôncavo Baiano. Magistra, 16, 33-41.

Padovan, M. P., Almeida, D. L., Guerra, J. G. M., Ribeiro, R. L. D., \& Ndiae, A. (2002). Avaliação de cultivares de soja, sob manejo orgânico, para fins de adubação verde e produção de grãos. Pesquisa Agropecuária Brasileira, 37(12), 1705-1710. https://doi.org/10.1590/S0100-204X2002001200005

Peluzio, J. M., Vaz-de-Melo, A., Afférri, F. S., Silva, R. R., Barros, H. B., Nascimento, I. R., \& Fidelis, R. R. (2009). Variabilidade genética entre cultivares de soja, sob diferentes condições edafoclimáticas. Pesquisa Aplicada \& Agrotecnologia, 2(3), 31-40.

Petter, F. A., Silva, J. A., Zuffo, A. M., Andrade, F. R., Pacheco, L. P., \& Almeida, F. A. (2016). Elevada densidade de semeadura aumenta a produtividade da soja? Resposta da radiação fotossinteticamente ativa. Bragantia, 75(2), 173-183. https://doi.org/10.1590/1678-4499.447

Rocha, R. S., Silva, J. A. L., Neves, J. A., Sediyama, T., \& Teixeira, R. C. (2012). Desempenho agronômico de variedades e linhagens de soja em condições de baixa latitude em Teresina-PI. Revista Ciências Agronômica, 43(1), 154-162. https://doi.org/10.1590/S1806-66902012000100019

Santos, J. M. S., Peixoto, C. P., Rangel, M. A. S., Cruz, T. V. C., Silva, R. N. A., \& Ledo, C. A. S. (2013) Desempenho agronômico de genótipos de soja hortaliça cultivados no recôncavo Baiano. Revista Brasileira de Ciências Agrárias, 8(3), 402-407. https://doi.org/10.5039/agraria.v8i3a2441

Smiderle, O. J., Oliveira, J. M. F., \& Schwengber, D. R. (2009). Desempenho de soja-hortaliça cultivada em área de cerrado em função de tipos de adubação. Revista Agro@mbiente On-line, 3(2), 86-91. https://doi.org/ 10.18227/1982-8470ragro.v3i2.271

Souza, C. A., Gava, F., Casa, R. T., Bolzan, J. M., \& Kuhnem Junior, P. R. (2010). Relação entre densidade de plantas e genótipos de soja Roundup Ready ${ }^{\mathrm{TM}}$. Planta Daninha, 28(4), 887-896. https://doi.org/10.1590/ S0100-83582010000400022

Tourino, M. C. C., Rezende, P. M., \& Salvador, N. (2002). Espaçamento, densidade e uniformidade de semeadura na produtividade e características agronômicas da soja. Pesquisa Agropecuária Brasileira, 37(8), 1071-1077. https://doi.org/10.1590/S0100-204X2002000800004

Vazquez, G. H., Carvalho, N. M., \& Borba, M. M. Z. (2008). Redução na população de plantas sobre a produtividade e a qualidade fisiológica da semente de soja. Revista Brasileira de Sementes, 30(2), 01-11. https://doi.org/10.1590/S0101-31222008000200001

Watanabe, R. T., Fioretto, R. A., Fonseca, I. B., Seifert, A. L., Santiago, D. C., Creste, J. E., \& Harada, A., Cucolotto, M. (2005). Produtividade da cultura de soja em função da densidade populacional e da porcentagem de cátions (Ca, Mg e K) no complexo sortivo do solo. Semina, 26(4), 477-484. https://doi.org/ 10.5433/1679-0359.2005v26n4p477

Zhang, Q., Gao, Q., Herbert, S. J., Li, Y., \& Hashemi, A. M. (2010). Influence of sowing date on phenological stages, seed growth and marketable yield of four vegetable soybean cultivars in Northeastern USA. African Journal Agricultural Research, 5(18), 2556-2562.

\section{Copyrights}

Copyright for this article is retained by the author(s), with first publication rights granted to the journal.

This is an open-access article distributed under the terms and conditions of the Creative Commons Attribution license (http://creativecommons.org/licenses/by/4.0/). 